УДК 616.155.194.8-07- 08

\title{
Актуальність та методи діагностики залізодефіцитної анемії в умовах високогір'я Закарпаття
}

\author{
М.Ю. Попович, М.В. Рішко \\ ДВНЗ «Ужгородський національний університет», Ужгород
}

\section{Реферат}

Розглянуто сучасний погляд на проблему залізодефіцитної анемії (ЗДА) з точки зору епідеміології, етіології, патогенезу в умовах високогір'я Закарпаття. У статті представлені сучасні методи лабораторної діагностики ЗДА, досліджено метаболізм заліза в організмі і патогенетичні механізми формування клінічних і лабораторних симптомів. Обговорюється діагностичне значення лабораторних методів, що застосовуються для діагностики ЗДА. Зроблено висновок про комплексний підхід при лабораторній діагностиці ЗДА. У рамках статті, автори пояснюють механізми низької ефективності лікування ЗДА і пропонують способи вирішення проблеми з урахуванням опублікованих в літературі останніх наукових досліджень.

Ключові слова: залізодефіцитна анемія, обмін заліза, діагностика, Закарпаття.

Relevance and methods of diagnosis of iron deficiency anemia in the highlands of Transcarpathia M. Popovych, M. Rishko

Uzhhorod National University, Uzhhorod

\begin{abstract}
Modern views of epidemiology, etiology, and pathogenesis of iron deficiency anemia (IDA) at the Zakarpattya high mountain region are considered. In the article, there are presented the modern methods of laboratory diagnostics of IDA. Some ideas on iron metabolism in the organism and pathogenetic mechanisms of clinical and laboratory symptomps are briefly presented. The diagnostic significance of laboratory methods for diagnosing IDA is discussed . There is made the conclusion about the integrated approach to the diagnostics of IDA. The causes of low treatment efficiency are discussed and the ways to address this problem are proposed on the base of the published results of clinical research.
\end{abstract}

Key words: iron deficiency anemia, iron metabolism, diagnostics, Zakarpattya.

Вступ. Дефіцит заліза (ДЗ) в організмі людини є дуже поширеним станом. Від нього страждає $1 / 5$ частина людства, особливо жінки дітородного віку і діти [3].

Проявом дефіциту заліза може бути розвиток залізодефіцитної анемії (ЗДА) [11]. У структурі всіх анемій питома вага залізодефіцитної анемії може досягати 80\%, в окремих країнах, наприклад, у Казахстані - до 90\% $[1,8]$. В Україні поширеність ЗДА в останні роки становить 1011,83 на 100 тис. дорослого населення, а захворюваність - 164, 11 на 100 тис. У той же час у Закарпатті поширеність ЗДА коливається в різні роки від 980,71 до 1245,34 на 100 тис. дорослого населення, а захворюваність - від 246,98 до 304,62 на 100 тис. дорослого населення [6-8]. Клінічні прояви ЗДА настільки різноманітні, що, незважаючи на давню історію вивчення, на сьогодні залишається актуальною проблемою іiі діагностика $[1,2,4,10]$. Практика показує недостатнє знання лікарями основних методів лабораторної діагностики ЗДА, що, очевидно, може відображатися на статистичних показниках і на несвоєчасному лікуванні. Крім того, можуть призначатися додаткові дослідження, найчастіше дорогі, втрачається дорогоцінний час на діагностику, що в кінцевому результаті несприятливо позначається на результатах лікування, оскільки наростають явища сидеропенії та пов'язані 3 нею метаболічні порушення.
Мета дослідження. Оцінка сучасних даних щодо особливостей клінічних проявів ЗДА в умовах високогір'я Закарпаття, основних методів ії лабораторної діагностики.

Коротко нагадаємо основні моменти щодо метаболізму заліза в організмі. Залізо відносять до макроелементів, оскільки його зміст в організмі дорослої людини перевищує 1 г і складає 4-6 г заліза (50 мг/кг маси у чоловіків і 35 мг/кг у жінок). У доношених новонароджених вміст заліза становить 70-75 мг/кг маси тіла $[8,10]$. Надходження екзогенного заліза в організм відбувається за рахунок його засвоєння 3 їжі. Фізіологічна потреба в залізі складається 3 компенсації його втрат з калом, сечею, потом, а також витрат на синтез гемоглобіну, міоглобіну, забезпечення діяльності ензимів, утворення запасів. Залізо, яке знаходиться в організмі, умовно можна розділити на: функціональне залізо (входить до складу еритрокаріоцитів кісткового мозку і циркулюючих еритроцитів, ферментів і міоглобіну), транспортне (зв'язане 3 трансферином), депоноване (пов'язане з феритином і гемосидерином) і залізо, яке утворює лабільний пул. Добова потреба дорослої людини в залізі становить 1,0-1,5 мг, з їжею всмоктується близько $10 \%$ заліза. Якщо запаси заліза в організмі є достатніми, то воно втрачається 3 епітелієм, що злущується, а коли $є$ дефіцит заліза, велика його частина, яка не затримуючись у слизовій, надходить у кровотік, де зв'язується з білком переносником трансферином. У 
слизовій кишківника $є$ транспортна система, яка регулює всмоктування заліза в залежності від потреби організму. Ця система розташована переважно в дванадцятипалій кишці і у верхньому відділі тонкої кишки. При ДЗ всмоктування здійснюється на всьому протязі кишківника. У клітинах слизової оболонки кишківника $є$ механізми швидкого і повільного обміну пулів заліза. Механізми проникнення зв'язаного заліза в клітини, його перенесення до апоферитину і звільнення його $з$ клітини в транспортну систему крові не до кінця встановлено, хоча багато в чому з'ясувалися після відкриття білка гепсидина, який на теперішній час вважається одним 3 основних регуляторних білків, що контролюють засвоєння заліза в кишківнику [8]. При Д3 зменшується синтез гепсидина в печінці, збільшується вміст трансферина і трансферинових рецепторів на поверхні ентероцитів, що супроводжується підвищенням абсорбції і транспортної здатності в клітинах слизової. Основна кількість заліза, яке необхідно організму для процесів синтезу, надходить 3 макрофагів при його рециркуляції зі старіючих еритроцитів. Цей процес здійснюється феропортином, гемовою оксидазою, дуоденальним транспортером двовалентних металів (DMT-1), а регулюється кількома протеїнами, до числа яких належать білок спадкового гемохроматоза (HFE), залізозв'язуючі елементи (IRE) i залізозв'язуючий протеїн (IRP). Як ми вже підкреслювали вище, ці процеси регулюються гепсидином $[1,8]$.

При досягненні балансу заліза частина його зберігається в клітинах у формі внутрішньоклітинного феритину. Апоферитин є зберігаючим білком для заліза. Ця ланка в ланцюзі метаболізму заліза є пулом повільного обміну заліза в ентероцитах. Якщо в ньому немає необхідності, то через кілька днів внутрішньоклітинний феритин елімінується при фізіологічному злущуванні епітеліальних клітин. Після того як залізо надійшло 3 просвіту кишківника в циркулюючу кров, воно з'єднується 3 трансферином плазми крові.

Трансферин - транспортний білок з молекулярною масою близько 88000 Д, відноситься до групи бета-глобулінів. Синтез трансферину відбувається в основному в печінці і в невеликих кількостях в лімфоїдній тканині, молочній залозі, тестикулах і яєчниках. Кожна молекула трансферину може зв'язувати 2 атома тривалентного заліза. У нормі трансферин насичений залізом не в повному обсязі, а приблизно на $30 \%$. Насичення трансферину є співвідношенням концентрації заліза сироватки до концентрації трансферину сироватки (корегуючий коефіцієнт 1,41) i визначається за формулою: насичення трансферину $(\%)=($ залізо (мкг/дл): (трансферин (мг/дл) х 1,41] х 100 .

Трансферин переносить залізо до еритрокаріоцитів кісткового мозку і в тканинні депо, здійснює його зворотний транспорт із макрофагів і тканинних депо в місця синтезу залізовмісних з'єднань. Комплекс залізо-трансферин зв'язується зі специфічними для трансферину рецепторами на клітинах органівмішеней. Металозв'язуюча ділянка молекули не $\epsilon$ специфічною для заліза. Трансферин може зв'язувати також кобальт, магній, мідь, цинк і хром, проте спорідненість до цих металів нижча, ніж до заліза, що обов'язково потрібно враховувати при призначенні комплексних препаратів заліза, що вміщують зазначені мікроелементи (вони будуть конкурувати із залізом за зв'язок з білками-переносниками, зменшуючи його біодоступність).

Роль трансферину зводиться також до зв'язування заліза, яке надійшло у надлишку, оскільки поза зв'язком з білком воно токсичне для організму. Багато клітин організму потребують трансферин для росту. В імунній системі присутність трансферину $є$ обов'язковою умовою для мітогенної проліферації Т-лімфоцитів. Трансферин відносять до білків гострої фази, що відображає імунологічну реактивність організму. Час напіврозпаду залізотрансферинового комплексу становить від 70 до 140 хв. Депонування заліза здійснюється білками феритином і гемосидерином. Феритин визначається майже у всіх тканинах, особливо висока тканинна концентрація і синтетична здатність в печінці, селезінці і кістковому мозку. Феритин має молекулярну масу 440000 Д. Білок у вільному від заліза вигляді називається апоферитином. Феритин складається 3 білкової оболонки, яка оточує ядро тривалентного заліза у вигляді комплексів окису і фосфату заліза. Кожна молекула апоферитину може абсорбувати до 5000 атомів заліза, проте більшість молекул феритину містять від 1000 до 3000 атомів заліза. Функція феритину зводиться в основному до створення запасів заліза і до швидкої мобілізації останнього в залежності від потреби. У здорових людей концентрація феритину в сироватці крові прямо корелює 3 кількістю депонованого заліза в організмі. Порівняльні дослідження показали, що при ДЗ, який не супроводжується соматичними захворюваннями, так само як i при первинному або вторинному перевантаженні залізом, показники феритину в сироватці крові дають досить точне уявлення про кількість заліза в організмі. Відповідно до цього, в клінічній діагностиці показник рівня феритину рекомендують використовувати як параметр, що дозволяє оцінювати пул депонованого заліза $[8,10]$.

Гемосидерин - білок-похідне феритину з більш високою концентрацією заліза. В організмі він присутній в основному при надмірному відкладенні заліза. Імунологічно підтверджено, що гемосидерин ідентичний феритину, але з більш високим вмістом заліза. Він виявляється в макрофагах кісткового мозку, селезінки, купферовских клітинах печінки. Гемосидерин містить тривалентне залізо в формі гідроксилу (29-35\% по масі). Гемосидерин легко розрізняється мікроскопічно, а також ідентифікується за допомогою гістохімічної реакції із жовтою кров'яною сіллю і соляною кислотою. 
За допомогою лабораторних методів дослідження можна кількісно оцінити: вміст заліза в сироватці (визначення сироваткового заліза); здатність сироватки транспортувати залізо (визначення трансферину в сироватці і відсоток насичення трансферина залізом, визначення загальної залізозв'язуючої здатності сироватки (333С); депонування і мобілізацію заліза з депо (визначення феритину сироватки); стан еритропоезу (підрахунок еритроцитів у периферійній крові); визначення концентрації гемоглобіну; вміст гемоглобіну в одному еритроциті (МНC), середнього обсягу еритроцитів (MCV); вміст гепсидина; дослідження пунктату кісткового мозку; цитохімічне визначення заліза в еритробластах і еритроцитах).

При дослідженні заліза сироватки крові слід враховувати, що його рівень схильний до впливу індивідуальних циркадних ритмів. Найбільш високий рівень заліза відзначають вранці, до ночі він поступово знижується. Зниження або збільшення концентрації заліза в сироватці крові здорової людини протягом доби може досягати 30\%, залишаючись в межах нормальних значень. Тому при контролі рівня заліза проби крові необхідно брати в один і той же час доби. Кров слід брати до прийому препаратів заліза або через 4-5 днів після їх відміни. При проведенні дослідження необхідно виключити потрапляння заліза ззовні в реакційну суміш. Проба для дослідження параметрів заліза не повинна мати слідів гемолізу. При зберіганні плазми в холодильнику при $4^{\circ} \mathrm{C}$ концентрація заліза в пробі практично не змінюється протягом кількох тижнів.

Кількісне визначення трансферину в сироватці крові можна проводити методами радіальної імунодифузії, лазерної нефелометрії з визначенням розсіювання при малих кутах відхилення, нефелометрії 3 використанням фотометрії. Приблизно концентрацію трансферину можна визначити по 333С.

У клінічній лабораторній діагностиці простіше визначити 333С, тому даний тест часто підміняє визначення трансферину. $€$ й аргументовані докази проти використання в практиці методу визначення 33ЗС сироватки крові для дослідженння трансферину, оскільки він зв'язується 3 преальбуміном, альбуміном, альфа-1-, альфа-2- і гаммаглобулінами сироватки крові. Тому зв'язуюча здатність, що вимірюється на 15-20\% вища, ніж справжня зв'язуюча здатність трансферину. Визначення 333С потребує значно більше крові, ніж при імунологічному визначенні трансферину. Це може мати істотне значення в педіатричній практиці, для важких хворих на гемодіалізі.

При визначенні феритину в сироватці крові радіоімунологічним методом або імуноферментним методом у однієї людини можуть бути отримані результати, які відрізняються.

Методи визначення вмісту гепсидина поки широко не розповсюджені через їх високу вартість і трудомісткість [8].

Фізіологічні втрати заліза у дітей складають $0,1-$ 0,3 мг/добу, підлітків - 0,5-1,0 мг/добу, дорослих 1,0-
1,5 мг/добу (у жінок, що мають менструації, втрати збільшуються до 2,5-3,0 мг/добу) [11].

Основними причинами дефіциту заліза $є$ недостатній його вміст в їжі і втрати 3 кровотечами. Виділяють три стадії формування дефіциту заліза: прелатентну, яка характеризується нормальним вмістом рівня гемоглобіну, кількості еритроцитів, показником гематокриту, концентрацією заліза в сироватці і його кількістю в депо, підвищеною резорбцією в тонкому кишківнику, наявністю в кістковому мозку сидеробластів; латентну, яка характеризується нормальними показниками периферичної червоної крові, зменшенням вмісту заліза в сироватці, збільшенням кількості зв'язаного заліза, підвищеною його абсорбцією в кишківнику, зникненням із кісткового мозку сидеробластів; стадію гіпохромнї анемії, яка характеризується зниженням показників периферичної червоної крові, зменшенням вмісту заліза в сироватці, збільшенням вмісту зв'язаного заліза і його резорбції в тонкому кишківнику, відсутністю в кістковому мозку сидеробластів.

Патогенетичним фактором дефіциту заліза $\epsilon$ його від’ємний баланс, зумовлений невідповідністю між споживанням з їжею, резорбцією, засвоєнням або підвищеними втратами 3 кровотечами [6]. Дефіцит заліза може виникати вторинно, при порушенні метаболізму інших мікроелементів - міді, цинку, марганцю, молібдену, ванадію та ін. Латентний дефіцит заліза характеризується зменшенням його тканинних запасів i транспортного фонду, але без зниження рівня гемоглобіну. ЗДА характеризується, крім перерахованого, ще й зменшенням вмісту гемоглобіну [2, 5, 11]. На відміну від більшості інших анемій, ЗДА, як правило, не супроводжується значним зменшенням кількості еритроцитів в одиниці об'єму крові [11]. Слід зазначити, що для високогір'я характерний розвиток вторинного симптоматичного еритроцитозу. Даний факт може нівелювати характерні зміни периферичної крові, властиві для ЗДА.

Терміни розвитку залізодефіцитного стану або наявність ознак ЗДА визначаються величиною запасів заліза $[1,2,8]$. Клінічні прояви ЗДА обумовлені наявністю анемічного і сидеропенічного синдромів. Анемічний синдром проявляється неспецифічними симптомами: загальною слабкістю, підвищеною втомленістю, сонливістю, зниженням працездатності, головним болем, запамороченнями, короткочасними втратами свідомості, серцебиттям, задишкою при ходьбі і фізичних навантаженнях, блідістю шкіри тощо. Сидеропенічний синдром зумовлений дефіцитом заліза в тканинах, і його проявами можуть бути: зміна шкірних покривів (їх сухість) і придатків шкіри - ламкість і смугастість нігтів, випадіння волосся, неможливість відростити довге волосся через їх ламкість, ангулярний стоматит, відчуття поколювання i печіння язика, спотворення смаку (ріса chlorotica) у вигляді пристрасті до неїстівних речей (крейди, попелу, глини, землі, льоду, зубної пасти тощо) і нюху - пристрасть до запаху гуми, бензину, паленого, фарби, ацетону тощо. У ротовій порожни- 
ні, як і по ходу всього травного тракту, виявляють атрофічні зміни, формується глосит. Морфофункціональні зміни травного тракту зумовлюють зниження апетиту i анорексію, сидеропенічну дисфагію, відрижку і навіть блювання після їжі. Спостерігають зменшення кислотоутворюючої функції шлунка, активності амілази, ліпази, трипсину. Наслідком зазначених змін у травному тракті $\epsilon$ формування синдрому мальабсорбції. Проявами сидеропенічного синдрому можуть бути енурез і дизуричні явища М'язову слабкість, що спостерігається у більшості осіб із ЗДА, пояснюють дефіцитом залізовмісних ензимів. Дистрофічні зміни склер очей проявляються специфічними змінами у вигляді симптому «блакитних склер» $[1,8,10]$.

Для лабораторної діагностики ЗДА використовують безліч методів. Перш за все, це гемоглобінометрія, визначення кількості еритроцитів і їх морфологічна характеристика, еритроцитометрія, визначення гематокритного числа, колірного показника та індексів еритроцитів, підрахунок кількості ретикулоцитів $[5,11]$. Доступним і в той же час інформативним показником, який $є$ одним 3 головних ознак ЗДА, $є$ колірний показник. Він відображає вміст гемоглобіну в еритроциті і представляє собою розрахункову величину [8]. Однак необхідно підкреслити, що гіпохромія не $\epsilon$ специфічною ознакою, характерною тільки для ЗДА. Гіпохромними можуть бути анемії, зумовлені дефіцитом міді, цинку, марганцю, порушенням обміну порфіринів, свинцевою інтоксикацією, інфекційними та запальними процесами [9, 11]. Зміни даного показника слід враховувати в комплексі з іншими лабораторними ознаками ЗДА. Відповідно до змін вмісту гемоглобіну ЗДА бувають: 3 легким перебігом (рівень гемоглобіну 110-90 г/л); із середнім (рівень гемоглобіну 89-70 г/л); важким (гемоглобін менше 69 г/л). Результати еритроцитометрії $€$ істотним моментом для уточнення характеру анеміі. Так, для ЗДА властиве зміщення еритроцитометричної кривої Прайс-Джонса вліво, оскільки в периферичній крові багато мікроцитів [11]. Мікроцитами називають еритроцити 3 діаметром 6,9 мкм i менше. У здорових людей еритроцити, в залежності від діаметра, поділяються таким чином: нормоцити (діаметр 7,0-8,0 мкм) - 68\%, мікроцити - 15,2\%, макроцити - діаметр 8,0 мкм і більше - 16, 8\%. Необхідно враховувати, що в період активації компенсаторно-пристосувальних механізмів адаптації організму до гіпоксії у осіб із ЗДА збільшується кількість макроцитів як відображення механізмів, спрямованих на іiі усунення. Виснаження цих механізмів призводить до переважання мікроцитоза в поєднанні 3 гіпохромією. 3'являються мішенеподібні еритроцити, анулоцити, а при глибокому дефіциті заліза краплевидні еритроцити (дакріоцити) і плантоцити. Анізоцитоз і пойкілоцитоз є лабораторними ознаками ЗДА.

Гематокрит дає уявлення про співвідношення між обсягами плазми і формених елементів. Цей показник використовують для оцінки ступеня анемії, а також для розрахунків величин, що відображають різні характеристики еритроцитів. Використання розрахунків з урахуванням відхилення на гематокритне число робить більш точними визначення вмісту біохімічних параметрів у пацієнтів 3 анеміями і еритроцитозами.

Показник MCH (Mean Corpuscular Hemoglobin) при ЗДА знижений, оскільки він відображає гіпохромію. Показник MCHC (Mean Corpuscular Hemoglobin Concentration) відображає ступінь насичення еритроциту гемоглобіном в процентах. Для ЗДА властиве зменшення даного показника. Середній обсяг еритроцитів MCV (Mean Corpuscular Volume) також знижений при ЗДА. Обчислюють показник шляхом ділення гематокритного числа на загальну кількість еритроцитів у 1 мкл крові. Середній діаметр еритроцитів вираховують шляхом множення кожного відсотка клітин $з$ певним діаметром на його значення в мкм, зведеним до суми цих поділів, і множення на 100. Для ЗДА властиве зниження цього показника відносно норми (7,55+0,099 мкм). Показник анізоцитозу еритроцитів (RDW) - poзраховують як коефіцієнт варіації MCV: RDW - SD / MCV x $100 \%$, де SD - стандартне середньоквадратичне відхилення об'єму еритроцитів від середнього значення. В нормі RDW станосить 11,5-14,5\%, а при ЗДА збільшується [8].

Слід зазначити, що анізоцитоз характеризує коливання об'єму еритроцитів і фіксується приладом при автоматичному підрахунку точніше, ніж при візуальній оцінці мазка крові. Оцінка ступеня анізоцитозу за допомогою мікроскопа може супроводжуватися цілою низкою помилок. При висушуванні еритроцитів у мазку крові їх діаметр зменшується на 10-20\%. У товстих мазках еритроцити менших розмірів, ніж в тонких. Позбутися від артефактів дозволяє тільки автоматизований підрахунок із застосуванням кондуктометричного методу.

Визначення кількості ретикулоцитів у крові $€$ суттєвим моментом лабораторної діагностики анемій. Для ЗДА характерний нормальний вміст ретикулоцитів. Ретикулоцити - це молоді еритроцити, які утворюються внаслідок втрати нормобластами ядер. За Гейльмеєром (1938) виділяють V ступенів зрілості. У здорової людини міститься від 2 до 10 ретикулоцитів на 1000 еритроцитів, причому в нормі трапляються тільки ретикулоцити III і IV ступеня зрілості у співвідношенні відповідно 1/3: 2/3. Посилена регенерація еритроїдного паростка кровотворення супроводжується збільшенням вмісту ретикулоцитів 0, I, II ступеня зрілості. Таке явище називають лівим зсувом ретикулоцитарного ряду. Збільшення кількості ретикулоцитів спостерігають при ЗДА на 7-10-ий день при патогенетично обгрунтованому лікуванні (ретикулоцитарний криз) $[8,11]$. Показник числа ретикулоцитів може бути використаний для оцінки ефективності еритропоезу.

Таким чином, еритроцити периферичної крові при ЗДА характеризуються гіпохромією, мікроцитозом, пойкілоцитозом (різна форма), анізоцитозом 
(різна величина), наявністю патологічних форм i, як правило, нормальною кількістю ретикулоцитів.

Показники метаболізму заліза при ЗДА характеризуються зменшенням вмісту заліза в сироватці (у нормі у чоловіків і жінок відповідно 13-30 і 12 25 мкмоль/л), збільшенням загальної залізозв'язуючої здатності сироватки крові (в нормі 3085 мкмоль /л). Різниця між показниками загальної залізозв'язуючої здатності сироватки крові і сироваткового заліза відображає латентну залізозв'язуючу здатність сироватки (в нормі менше 47 мкмоль/л). При ЗДА цей показник підвищений. Співвідношення показника заліза сироватки i загальної залізозв'язуючої здатності відображає насичення трансферину залізом (норма 16-50\%). При ЗДА цей показник знижується. ЗДА характеризується зменшенням вмісту феритину у сироватці крові (норма 15-150 мкг/л). Оцінка запасів заліза в організмі, крім визначення показника феритину, може бути здійснена за допомогою десфералового тесту [8]. Визначення протопорфіринів в еритроцитах пацієнтів із ЗДА показує їх збільшення (норма 18-89 мкмоль). За даними радіологічних досліджень виявляють збільшення кліренсу заліза плазми.

Таким чином, лабораторним критерієм ЗДА є гіпохромна анемія, яка супроводжується морфологічними змінами еритроцитів, зменшенням вмісту сироваткового заліза, збільшенням загальної залізозв'язуючої здатності сироватки крові, зменшенням насичення трансферину залізом і зниженням концентрації феритину у сироватці крові.
Анемія є типовим патологічним процесом, при виникненні якого розвивається інший патологічний процес - гіпоксія. Доведено, гіпоксія супроводжується цілим каскадом змін в організмі, що в кінцевому результаті призводить до оксидативного стресу (ОС). Гемічна гіпоксія як типовий патологічний процес формується не тільки за рахунок зниження кисневої ємності крові, але й за рахунок порушення кисневозв'язуючих властивостей гемоглобіну, процесів транспорту кисню кров'ю і утилізації кисню тканинами - тобто простежується полімодальний етіопатогенез [5-7, 9]. Без сумніву, в умовах високогір'я Закарпаття ці процеси підсилюються і мають важливе значення у патогенезі вторинних метаболічних порушень у пацієнтів при ЗДА.

Висновки. 1. ЗДА в умовах високогір'я Закарпаття $\epsilon$ поширеним захворюванням і характеризується специфічними механізмами формування клінічних та лабораторних проявів.

2. Тільки комплексна оцінка лабораторних і клінічних даних, їх всебічний аналіз дозволяють встановити точний діагноз ЗДА. Необхідний загальноприйнятий комплекс лабораторних методів, застосування яких значно підвищує верифікацію діагнозу i скорочує час діагностичних пошуків при ЗДА.

3. Слід проводити моніторинг показників периферичної крові (ретикулоцити, морфологія еритроцитів, параметри трансферину, феритину) для контролю та планування препаратів, що будуть застосовуватися при лікуванні ЗДА.

\section{Автор заявляє про відсутність конфлікту інтересів.}

\section{Список використаної літератури}

1. Bajdurin S. Klinicheskoje gematologija: rukovodstvo dlje vrachej. Karaganda: AKHYP. 2018;400. [In Russian].

2. Benoist B. Worldwide prevalence of anemia 1993-2005, WHO global database of anemia. Geneva. World Health Organization. 2008. [In English].

3. Davydova Y, Limanskaja A, Ogorodnik S. Zelezodeficitnaja anemija v XXI veke: ionnye i nelonnye preparaty zeleza prakticheskie rekomendacii dla beremennyh. Zdorov je zenschiny. 2018;3(79):25-29. [In Ukrainian].

4. Guseva S., Oleynik V. Sovremennye vzglady na metabolism zeleza. Ukrajinski zurnal gematologli transfusiologi. 2012;6(17):27-33. [In Ukrainian].

5. Novak V., Masljak Z. Buzerak N. Berg L, Primak 5, Gutor T. Pokaznyky dijolnosti gematologichnoji sluzby Ukrajiny v 2014 rozi. Lviv.2015;42 [In Ukrainian].

6. Novak V. Masljak Z. Ziapka O, Buzerak N, Gutor T, Adzigitova L. Pokaznyky dijalnosti gematologichnoji sluzby Ukrajiny v 2010 razi. Lviv. 2011;36. [In Ukrainian].

7. Romanenko T. Morozova O, Sulimenko O. Prophilaktika ta likuvannya zalizodefizytnoi anemii pry bagatoplidni vagitnosti. Health of woman. 2020;4(150):51-56. [In Ukrainian].

8. Rukavitsyn O. Aktualnie voprosy diagnostik I lechenija anemii pri chronicheskith zabolevanijach. Klinicheskoja oncogematologia.2012;5(4):296-304. [In Russian].

9. Rukavitsin O. (ed.) Gematologija: nazional'noe rukovodstvo. Moscow: Izdatelskaja gruppa GEOTARMedia. 2015;776. [In Russian].

10. Stuklov N. Semenova E. Zelezodeficitnaja anemija. Sovremennaja taktika diagnostiki i lechenija. Kriterii effectivnosti terapii. Zhurnal mezhdunarodnoj meditsiny. 2013;1(2):47-55. [In Russian].

11. Vydyborets S. (2015) Korrekcija deficita geleza: sovremennye aspekti. Gematologijia Transfusiologija. Vostochnaja Evropa. 2015;1:117-122. [In Ukrainian].

Стаття надійшла до редакції: 23.10 .2020 р. 